\title{
MAGNESIUM SERUM AND URINE CONCENTRATION IN PATIENTS WITH ACUTE AND CHRONIC PULMONARY DISEASE
}

\author{
Ljudmila Nagorni-Obradović1, Suetlana Ignjatović2 ${ }^{2}$, Vesna Petrović1 ${ }^{1}$, Marija Mitić-Milikić1 \\ IInstitute for Pulmonary Diseases and Tuberculosis, Clinical Centre of Serbia and University \\ School of Medicine, Višegradska 26, 11000 Belgrade, Serbia and Montenegro \\ 2Institute of Medical Biochemistry, Clinical Centre of Serbia and University School of Pharmacy, \\ Višegradska 26, 11000 Belgrade, Serbia and Montenegro
}

\begin{abstract}
Summary: In this study we determined magnesium concentration in serum and in 24-hour urine, at the start (To) and at the end of treatment (T1), in 56 patients with acute pulmonary disease (B1) and in 58 patients with chronic obstructive pulmonary disease - COPD (B2). In group B1 there was disbalance of $\mathrm{Mg}$ in serum in $14-25 \%$ patients at the start of treatment (To) which decreased significantly at the end of treatment (T1) and persisted in $4-7.1 \%$ patients ( $\mathrm{p}<0.05$ ). In group B2 distribution of normal, decreased and increased values of $\mathrm{Mg}$ in serum was similar in patients in period To and T1 ( $p>0.05)$. In group B1, 9 (16.1\%) patients had hypomagnesemia at the start of treatment (To), which was accompanied by increased concentration of $\mathrm{Mg}$ in 24-hour urine of only $4(7.2 \%)$ patients. There is a possibility that there was extrarenal elimination of $\mathrm{Mg}$ in patients with acute pulmonary disease or there was some kind of transcellular distribution. In group B2 in period To, there was proportional ratio between hypomagnesemia (12-20.7\% patients) and increased concentration of $\mathrm{Mg}$ in 24-hour urine (20-34.5\% patients). This could be because of renal loss. Simultaneous determination and follow up of magnesium in serum and in 24-hour urine can give us reliable information about homeostasis of this electrolyte in acute and chronic pulmonary diseases.
\end{abstract}

Key words: magnesium, serum, urine, pulmonary disease

\section{Introduction}

Body magnesium is distributed in three major compartments: extracellular fluid (1.3\%), intracellular fluid (13\%) and bone (67\%). Thus, $\mathrm{Mg}$ is mainly located in areas that are poorly accessible to study: the intracellular and body compartments. Unfortunately, most of the available data on electrolyte metabolism is derived from measurements of the blood concentration of $\mathrm{Mg}$. Today we can diagnose $\mathrm{Mg}$ disbalance measuring this electrolyte in extracellular fluid (serum), intracellular fluid (erythrocyte, lymphocyte) and urine $(1,2)$. Lymphocyte and skeletal muscle $\mathrm{Mg}$ have been used for research purposes, but usually are not avail-

Address for correspondence

Ass. dr. sci. med. Ljudmila Nagorni-Obradović Institute for Pulmonary Disease and Tuberculosis

Clinical Centre of Serbia, Višegradska 26

11000 Belgrade, Serbia and Montenegro able in clinical practice because of the complexity of their determination. Determination of erythrocyte $\mathrm{Mg}$ value is the most precise, since $\mathrm{Mg}$ is primarily an intracellular cation, but many laboratories are deficient in this method. It is sometimes extremely difficult to precisely judge body $\mathrm{Mg}$ content in clinical reports and experimental studies that measure only the serum levels. Hypomagnesemia can develop without concomitant magnesium losses and cellular magnesium depletion can occur in the presence of normomagnesemia (3). However, with all its limitations, a serum Mg concentration remains the prime clinical diagnostic tool. Simultaneous investigation of $\mathrm{Mg}$ in serum and in 24-hour urine is a precious method for observation of $\mathrm{Mg}$ disbalance in clinical practice. Serum Mg concentration is not routinely measured when physicians initiate a request for determination of serum electrolytes. Various studies indicated that patients with acute and chronic pulmonary disease may have $\mathrm{Mg}$ disbalance (1-2, 4-5). 


\section{Materials and Methods}

\section{Materials}

We investigated 114 patients, 56 with acute pulmonary disease (B1) (with the subgroups B1-1: 18 patients with pneumonia, B1-2: 22 patients with pulmonary thromboembolism, B1-3: 16 patients with acute asthma attack) and 58 patients with acute exacerbation of chronic obstructive pulmonary disease COPD (B2). The following ratio between males and females were in group B1 $=34-60.7 \%: 22-39.3 \%$ $(\mathrm{B} 1-1=14-77.8 \%: 4-22.2 \%$; B1-2 $=13-59.1 \%: 9$ $-40.9 \%$; $\mathrm{B} 1-3=7-43.8 \%: 9-56.2 \%)$ and in group B2 $=33-56.9 \%: 25-43.1 \%$. In group B1 patients were of mean age $46.8 \pm 15.3$ years (B1-1: $47.1 \pm$ 15.9; B1-2: $49.7 \pm 13.4$; B1-3: $42.2 \pm 16.9)$ and 61.7 \pm 7.7 years in group B2.

\section{Methods}

We measured $\mathrm{Mg}$ concentration in serum and 24 hour urine in patients by colorimetric Calmagite method using biochemical analyzer IL Monarch 2000 (Instrumentation Laboratory, Milano, Italy). Reference values for $\mathrm{Mg}$ in serum were $0.70-1.15 \mathrm{mmol} / \mathrm{L}$ and in $24-$ hour urine were 3-5 mmol/day (6).

We determined $\mathrm{Mg}$ concentration in serum and 24-hour urine in patients at the start (To) and at the end of hospital treatment (T1). All patients were first admitted in Pulmonary Intensive Care Unit and after stabilization of disease they continued treatment in the clinical department.

In this study there were not patients with associate diseases which can be a potential risk factor for electrolyte disbalance like: gastrointestinal diseases (Malabsorption syndromes, ulcus disease, malnutrition for hard dietary, severe diarrhoea, pancreatitis, etc.), pregnancy and prolonged lactation, hormonal diseases (Diabetes mellitus, hyperthyroidism, hypothyroidism, diseases glandulae suprarenalis, etc), renal failure, malignant disease, and alcoholism.

The results are presented as mean values $(\bar{x})$ with dispersion measures: standard deviation (SD), coefficient of variation (CV) and standard error (SE), minimal and maximal values (Min-Max) and median values. A statistical analysis was performed using Student's t-test, Mann-Whitney test and Pearson's $\chi^{2}$ test. Differences were considered as statistically significant at $\mathrm{p}<0.05$.

\section{Results}

In the group of patients with acute pulmonary disease (B1) 22 patients (39.3\%) had high temperature over $38{ }^{\circ} \mathrm{C}$ and in the group with acute exacerbation of chronic obstructive pulmonary disease - COPD (B2) were 27 patients $(18.7 \%)\left(\chi^{2}=0.614\right.$; DF $=1$, $\mathrm{p}>0.05)$. On hospital admission 45 patients (80.3\%) with acute pulmonary diseases (B1) had acute disturbance of respiratory gasses in arterial blood. Partial pressure of oxygen in arterial blood $\left(\mathrm{PaO}_{2}\right)$ was lower than $8 \mathrm{kPa}$ in 7 patients (38.9\%) with pneumonia (B11 ), in 5 patients $(22.7 \%)$ with pulmonary thromboembolism (B1-2) and in 9 patients (56.3\%) with acute asthma attack (B1-3). In group B2 on admission all 58 patients (100\%) had acute exacerbation of chronic respiratory failure. Mean value of $\mathrm{PaO}_{2}$ in group $\mathrm{B} 1$ was $8.85 \pm 1.65 \mathrm{kPa}$ and in $\mathrm{B} 24.86 \pm 0.92 \mathrm{kPa}(\mathrm{t}=$ 15.964; $\mathrm{DF}=1, \mathrm{p}<0.001$ ). Decompensation status of cor pulmonale chronicum persisted in 39 patients (67.2\%) with acute exacerbation of COPD (B2).

Table I Magnesium concentration in serum $(\mathrm{mmol} / \mathrm{L})$ at the start (To) and at the end of treatment (T1) in groups of patients

\begin{tabular}{|l|c|c|c|c|c|c|c|}
\hline To \\
\hline Group & $\mathrm{n}$ & $\overline{\mathrm{x}}$ & SD & SE & CV $(\%)$ & Min-Max & Median \\
\hline B1 & 56 & 0.88 & 0.16 & 0.02 & 18.2 & $0.48-1.27$ & 0.87 \\
\hline B1-1 & 18 & 0.88 & 0.14 & 0.03 & 15.9 & $0.62-1.21$ & 0.89 \\
\hline B1-2 & 22 & 0.86 & 0.15 & 0.03 & 17.4 & $0.65-1.27$ & 0.85 \\
\hline B1-3 & 16 & 0.90 & 0.21 & 0.05 & 23.3 & $0.48-1.23$ & 0.91 \\
\hline B2 & 58 & 0.86 & 0.16 & 0.02 & 18.6 & $0.58-1.45$ & 0.85 \\
\hline $\mathrm{t}=0.649 ; \mathrm{DF}=112 ; \mathrm{p}>0.05 *$ \\
\hline T1 \\
\hline Group & $\mathrm{n}$ & $\overline{\mathrm{x}}$ & SD & SE & CV $(\%)$ & Min-Max & Median \\
\hline B1 & 56 & 0.94 & 0.17 & 0.02 & 18.0 & $0.68-1.86$ & 0.95 \\
\hline B1-1 & 18 & 0.91 & 0.12 & 0.02 & 13.1 & $0.69-1.10$ & 0.91 \\
\hline B1-2 & 22 & 0.97 & 0.23 & 0.05 & 23.7 & $0.68-1.86$ & 0.96 \\
\hline B1-3 & 16 & 0.92 & 0.13 & 0.03 & 14.1 & $0.70-1.16$ & 0.93 \\
\hline B2 & 58 & 0.87 & 0.14 & 0.02 & 16.0 & $0.66-1.19$ & 0.88 \\
\hline $\mathrm{t}=2.094 ;$ DF $=112 ; \mathrm{p}<0.05 *$ \\
B1 - t = 1.788; p > 0.05* \\
B2 - t = 1.631; p > 0.05* \\
\hline * Student's t-test \\
\hline
\end{tabular}

In patients with acute pulmonary disease (B1) the most lowest value of $\mathrm{Mg}$ in serum on admission (To) was $0.48 \mathrm{mmol} / \mathrm{L}$ and the highest was $1.27 \mathrm{mmol} / \mathrm{L}$. The mean concentration of this electrolyte was in reference range $(0.88 \pm 0.16 \mathrm{mmol} / \mathrm{L})$. In patients with acute exacerbation of COPD (B2) mean concentration of $\mathrm{Mg}$ in serum in period To $(0.86 \pm 0.16 \mathrm{mmol} / \mathrm{L})$ was normal like in group B1 (B1:B2 $t=0.649$; DF $=112$, $\mathrm{p}>0.05)$. After administered therapy at the end of hospitalization (T1) in both groups mean concentration of $\mathrm{Mg}$ in serum was normal but lower in group B2 (0.87 \pm $0.14 \mathrm{mmol} / \mathrm{L})$ than in group B1 $(0.94 \pm 0.17 \mathrm{mmol} / \mathrm{L})$ $(\mathrm{t}=2.094$; $\mathrm{DF}=112$, $\mathrm{p}<0.05)$. By comparing individual analyses within group B1 and group B2 there were not statistically significant differences in mean concentrations of $\mathrm{Mg}$ in serum before (To) or after treatment $(\mathrm{T} 1)(\mathrm{p}>0.05)($ Table I). 
Table II. Distribution of magnesium concentration in serum at the start (To) and at the end of treatment (T1)

\begin{tabular}{|c|c|c|c|c|c|c|c|c|c|c|c|c|c|c|}
\hline \multirow{4}{*}{$\begin{array}{l}\text { Group } \\
\text { B1 }\end{array}$} & \multirow{4}{*}{$\begin{array}{l}N \\
56\end{array}$} & \multicolumn{6}{|c|}{ To } & \multicolumn{6}{|c|}{$\mathrm{T} 1$} & \multirow{2}{*}{$\mathrm{p}$} \\
\hline & & \multicolumn{2}{|c|}{ Normal* } & \multicolumn{2}{|c|}{ Decreased* } & \multicolumn{2}{|c|}{ Increased* } & \multicolumn{2}{|c|}{ Normal* } & \multicolumn{2}{|c|}{ Decreased* } & \multicolumn{2}{|c|}{ Increased* } & \\
\hline & & $\mathrm{n}$ & $\%$ & $\mathrm{n}$ & $\%$ & $\mathrm{n}$ & $\%$ & $\mathrm{n}$ & $\%$ & $\mathrm{n}$ & $\%$ & $\mathrm{n}$ & $\%$ & \\
\hline & & 42 & 75.0 & 9 & 16.1 & 5 & 8.9 & 52 & 92.9 & 3 & 5.3 & 1 & 1.8 & $<0.05$ \\
\hline B1-1 & 18 & 15 & 83.3 & 2 & 11.1 & 1 & 5.6 & 17 & 94.4 & 1 & 5.6 & - & - & $>0.05$ \\
\hline B1-2 & 22 & 18 & 81.8 & 3 & 13.6 & 1 & 4.5 & 19 & 86.4 & 2 & 9.1 & 1 & 4.5 & $>0.05$ \\
\hline B1-3 & 16 & 9 & 56.2 & 4 & 25.0 & 3 & 18.8 & 16 & 100 & - & - & - & - & $<0.05$ \\
\hline B2 & 58 & 43 & 74.1 & 12 & 20.7 & 3 & 5.2 & 46 & 79.3 & 10 & 17.2 & 2 & 3.4 & $>0.05$ \\
\hline \multicolumn{8}{|c|}{ B1:B2 } & \multicolumn{7}{|c|}{$\chi^{2}=4.33 ; \quad D F=1 ; \quad p<0.05^{* *}$} \\
\hline
\end{tabular}

Table III Magnesium concentration in 24-hour urine (mmol/day) at the start (To) and the end of treatment (T1) in groups of patients

\begin{tabular}{|c|c|c|c|c|c|c|c|}
\hline \multicolumn{8}{|l|}{ To } \\
\hline Group & $\mathrm{n}$ & $\overline{\mathrm{x}}$ & SD & SE & CV (\%) & Min-Max & Median \\
\hline B1 & 56 & 3.04 & 1.87 & 0.25 & 61.5 & $0.08-8.40$ & 2.99 \\
\hline B1-1 & 18 & 2.84 & 1.46 & 0.36 & 51.4 & $0.24-4.90$ & 3.24 \\
\hline B1-2 & 22 & 2.73 & 2.06 & 0.43 & 75.4 & $0.20-7.32$ & 2.58 \\
\hline B1-3 & 16 & 3.67 & 1.92 & 0.48 & 52.3 & $0.08-8.40$ & 3.58 \\
\hline B2 & 58 & 3.98 & 2.41 & 0.31 & 60.5 & $0.05-11.20$ & 3.97 \\
\hline \multicolumn{8}{|c|}{$Z=2.553 ; p<0.015^{*}$} \\
\hline \multicolumn{8}{|l|}{$\mathrm{T} 1$} \\
\hline Group & $\mathrm{n}$ & $\overline{\mathrm{x}}$ & SD & SE & CV (\%) & Min-Max & Median \\
\hline B1 & 56 & 2.67 & 1.69 & 0.27 & 63.2 & $0.05-6.60$ & 2.85 \\
\hline B1-1 & 18 & 2.76 & 1.57 & 0.45 & 56.8 & $0.48-5.90$ & 2.72 \\
\hline B1-2 & 22 & 1.44 & 1.86 & 0.62 & 129.1 & $0.05-5.05$ & 0.50 \\
\hline B1-3 & 16 & 3.28 & 1.39 & 0.34 & 42.3 & $0.94-6.60$ & 3.33 \\
\hline B2 & 58 & 4.28 & 2.82 & 0.37 & 65.8 & $0.09-17.70$ & 3.71 \\
\hline \multicolumn{8}{|c|}{$\begin{array}{l}Z=5.492 ; p<0.001^{*} \\
B 1-Z=0.958 ; p>0.05^{*} \\
B 2-Z=0.019 ; p>0.05^{*}\end{array}$} \\
\hline \multicolumn{8}{|c|}{ *Mann-Whitney test } \\
\hline
\end{tabular}

In comparison with reference values (normal, decreased and increased), patients with acute pulmonary disease (B1) had important differences in distribution of $\mathrm{Mg}$ serum concentration at the start (To) (normal $=75.0 \%$; decreased $=16.1 \%$; increased $=$ $8.9 \%$ ) and at the end of treatment (T1) (normal = 92.9\%; decreased $=5.3 \%$; increased $=1.8 \%)(\mathrm{p}<$ $0.05)$. There is an interesting occurrence disbalance in this electrolyte in serum in patients with acute asthma attack (To) (43.8\% patients had disturbance). Among them, $25 \%$ of patients had decreased and $18.8 \%$ increased concentration of magnesium. After therapy (T1) this disbalance was completely corrected and all patients had normal concentration of $\mathrm{Mg}(\mathrm{p}<0.05)$. Patients with acute exacerbation of COPD (B2) had similar values, normal, decreased and increased con- centrations before and after therapy ( $p>0.05$ ). Comparing $\mathrm{Mg}$ distribution in serum between groups B1 and B2 we registered not significant differences in period To $\left(\chi^{2}=0.032\right.$; $\left.\mathrm{DF}=1, \mathrm{p}>0.05\right)$ but significant in period T1 $\left(\chi^{2}=4.33 ; \mathrm{DF}=1, \mathrm{p}<0.05\right)(\mathrm{Ta}-$ ble $I I)$.

Mean concentration of $\mathrm{Mg}$ in 24-hour urine in patients from group B1 and group B2 at period To and T1 was shown in Table III.

In Table $I V$ we can see distribution normal, decreased and increased concentrations of $\mathrm{Mg}$ in 24hour urine in patients from group B1 and group of B2. There are interesting findings in group B2 where patients had high percentage of increased concentration of $\mathrm{Mg}$ in 24-hour urine both at the start (To) and at the end of treatment (T1).

\section{Discussion}

Disbalance of $\mathrm{Mg}$ serum concentration is not a rare appearance in patients with pulmonary diseases (1-4). Results from literature described frequency of hypomagnesemia in 10-60\% among hospital treated patients, especially in patients who were medically treated in Intensive Care Units. Greater mortality was seen in patients with hypomagnesemia, comparing with patients who had normal concentrations, especially when they were treated in Intensive Care Unit (7).

Results of this study showed that mean concentration of $\mathrm{Mg}$ in serum at the start (To) and at the end of medical care (T1) were in referential value in group B1 and group B2.

Analyzing various patients in group B1 we found that patients with acute asthma attack (B1-3) had the lowest $\mathrm{Mg}$ serum concentration in period To $(0.48$ $\mathrm{mmol} / \mathrm{L})$ while the highest concentration $(1.27 \mathrm{mmol} / \mathrm{L})$ was found in patients with pulmonary thromboembolism (B1-2).

Patients with acute pulmonary disease (B1) had important differences in distribution of $\mathrm{Mg}$ serum con- 
Table IV Distribution of magnesium concentration in 24-hour urine at the start (To) and at the end of treatment (T1)

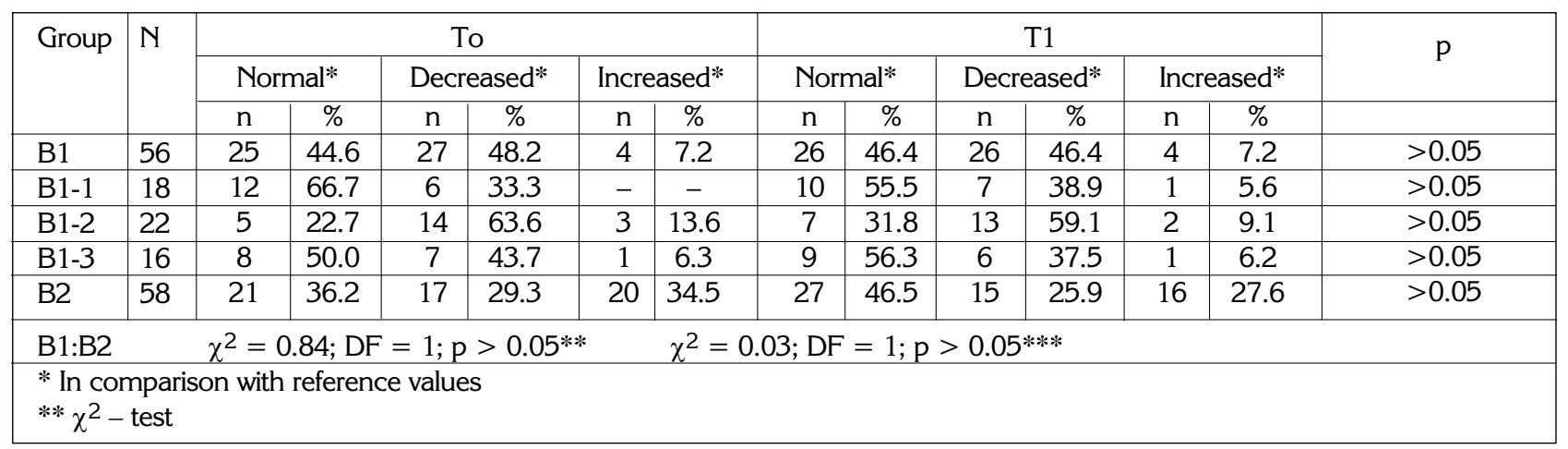

centrations between the start (To) and the end of treatment $(\mathrm{T} 1)(\mathrm{p}<0.05)$. They had hypomagnesemia (16.1\% patients) more frequently than hypermagnesemia ( $8.9 \%$ patients) at the start of hospitalisation. Total $\mathrm{Mg}$ serum disbalance was present in $25 \%$ patients of group B1 in period To, which is similar to results of other authors. They therefore recommended that serum $\mathrm{Mg}$ be included routinely when serum electrolyte measurements are required in the care of patients (8, 9). Hypomagnesemia in patients with acute pulmonary disease may be a result of severe infections, inappropriate secretion of antidiuretic hormone (ADH), antibiotic administration (aminoglycoside) (3), etc.

Hypomagnesemia was more frequently found in patients with acute asthma attack (B1-3: 25.0\% patients) than in patients with pneumonia (B1-1: $11.1 \%$ patients) and patients with pulmonary thromboembolism (B1-2: $13.6 \%$ patients).

There was an interesting appearance that $43.8 \%$ patients with acute asthma attack (B1-3) had Mg serum disturbance in a period of bronchoobstruction which was the reason for hospital care. After medical treatment all disbalances were corrected $(p<0.05)$. Patients had hypomagnesemia (25.0\%) more commonly than hypermagnesemia (18.8\%). Some authors did not discover $\mathrm{Mg}$ disbalance in patients with asthma attack (10), but others confirmed significant disturbance of this electrolyte usually as hypomagnesaemia (11). Mg depletion may affect muscle function (3), so hypomagnesemia can be one of the reasons for appearance of bronchoobstruction in patients with asthma attack. Various medicaments can produce $\mathrm{Mg}$ and other electrolyte disturbance. Frequently administered nebulized albuterol (beta-adrenergic agonist) during the emergency treatment of acute bronchospasam in patients with asthma decreases serum potassium, magnesium and phosphate (12). Intravenous theophylline administered in patients with asthmatic attacks can produce hypophosphatemia, hypomagnesaemia and hypocalcaemia (2). Hashimoto (11) confirmed decreased $\mathrm{Mg}$ in $40 \%$ patients with asthma and he compared it with severity of bronchoobstruction. The majority of authors advised administration of magnesium-sulfate to improve pulmonary function in patients with acute asthma attack (13-15). Continuous medical treatment with oral magnesium $300 \mathrm{mg} /$ day during two months reduces asthma morbidity in children and adolescents, and helps to improve their lung function (14). Besides recommended treatment by Global Strategy for Asthma Management and Prevention (16), administration of $2 \mathrm{~g}$ IV magnesium sulfate improves pulmonary function when used as an adjunct to standard therapy in patients with very severe acute asthma (15).

We can expect different electrolyte disbalance, also $\mathrm{Mg}$ disturbance in patients with acute pulmonary disease (17).

In $25.9 \%$ patients at the start acute exacerbation of COPD (B2) Mg serum disbalance persisted more frequent as hypomagnesaemia (20.7\% patients) than hypermagnesiemia ( $5.2 \%$ patients). Comparing distribution of $\mathrm{Mg}$ in serum between patients in group B1 and B2 we confirmed not significant differences et the start (To) $\left(\chi^{2}=0.032\right.$; DF $\left.=1 ; \mathrm{p}>0.05\right)$ but significant differences at the end of treatment (T1) $\left(\chi^{2}=\right.$ 4.33; $\mathrm{DF}=1 ; \mathrm{p}<0.05)$.

Various electrolyte disbalance is not an uncommon appearance in patients with acute exacerbation of COPD (18). In this study there were a greater number of patients with decreased $\mathrm{Mg}$ in serum (20.7\%) than in results of Hogg et al (11.8\%) (19). There is a study which shows that exacerbation of COPD significantly affected magnesium levels in erythrocytes, while in plasma levels it remained unchangeable (20). Administration of systemic corticosteroids and diuretics can be a possible reason for hypomagnesemia in patients with acute exacerbation of COPD (4).

Comparing distribution of $\mathrm{Mg}$ concentration in serum and in 24-hour urine in patients of group B1 at the start of treatment (To), it was not confirmed that hypomagnesemia (16.1\% patients) was in proportional ratio with increased urine concentration $(7.2 \%$ patients). Therefore was suspected that patients with acute pulmonary disease had extrarenal electrolyte 
elimination or transcellular arrangement from extracellular to intracellular space. In patients of group B2 also at the start of hospital care (To) there was a better proportional ratio between decreased $\mathrm{Mg}$ in serum (20.7\% patients) and increased urine level (34.5\% patients). We explained these results by renal electrolyte elimination, mostly because of using loop diuretics in patients who had cor pulmonale chronicum in decompensated state.
Results of this study showed that we can expect magnesium disbalance in patients with acute and chronic pulmonary diseases. Measuring $\mathrm{Mg}$ in serum and in 24-hour urine is a very useful method for followup of electrolyte disturbance. We recommend that should be determined and followed up $\mathrm{Mg}$ concentration in pulmonary diseases especially in patients with acute asthma attack.

\title{
KONCENTRACIJA MAGNEZIJUMA U SERUMU I URINU KOD BOLESNIKA SA AKUTNIM I HRONIČNIM PLUĆNIM BOLESTIMA
}

\author{
Ljudmila Nagorni-Obradović ${ }^{1}$, Suetlana Ignjatović ${ }^{2}$, Vesna Petrović ${ }^{1}$, Marija Mitić-Milikić1 \\ ${ }^{1}$ Institut za plućne bolesti i tuberkulozu, Klinički centar Srbije i Medicinski fakultet \\ Univerziteta u Beogradu, Višegradska 26, 11000 Beograd, Srbija i Crna Gora \\ 2Institut za medicinsku biohemiju, Klinički centar Srbije i Farmaceutski fakultet \\ Univerziteta u Beogradu, Višegradska 26, 11000 Beograd, Srbija i Crna Gora
}

\begin{abstract}
Kratak sadržaj: U ovom radu određivana je koncentracija magnezijuma u serumu i u 24-urinu, na početku (To) i na kraju hospitalnog lečenja (T1) kod 56 bolesnika sa akutnim plućnim bolestima (B1) i kod 58 sa hroničnim plućnim bolestima (B2). U grupi B1 postojao je disbalans $\mathrm{Mg}$ u serumu kod $14-25 \%$ bolesnika na početku lečenja (To) koji se značajno smanjio na kraju lečenja (T1) i postojao je kod $4-7,1 \%$ bolesnika $(p<0,05)$. U grupi B2 distribucija normalnih, snizenih i povišenih vrednosti Mg u serumu bila je slična u periodu To i T1 (p> 0,05). Hipomagnezemiju u grupi B1 imalo je $9(16,1 \%)$ bolesnika na početku lečenja (To) što je bilo praćeno povećanom koncentracijom Mg u 24-časovnom urinu samo kod 4 (7,2\%) bolesnika. Ovo je bilo moguće zbog ekstrarenalnog gubitka elektrolita ili je došlo do transcelularne preraspodele. U grupi B2 u periodu To postojao je proporcionalni odnos hipomagnezemije (12,0-20,7\% bolesnika) sa povećanom koncentracijom Mg u 24-časovnom urinu (20,0-34,5\% bolesnika). Ovo je bilo moguće zbog renalne eliminacije elektrolita. Istovremeno određivanje i praćenje magnezijuma u serumu i 24-časovnom urinu daje pouzdane informacije o homeostazi ovog elektrolita kod akutnih i hroničnih plućnih bolesti.
\end{abstract}

Ključne reči: magnezijum, serum, urin, plućne bolesti

\section{References}

1. de-Valk HW, Kok PT, Struyvenberg A, van-Rijn HJ, Haalboom JR, Kreuknier J et al. Extracellular and intracellular magnesium concentrations in asthmatic patients. Eur Respir J 1993; 6 (8): 1122-5.

2. Knutsen R, BohmerT, Falch J. Intravenous theophylline induced excretion of calcium, magnesium and sodium in patients with recurrent asthmatic attack. Scand J Clin Lab Invest 1994; 54: 119-25.

3. Agus SZ, Massry GS. Hypomagnesemia and hypermagnesemia. In: Maxwell HM, Kleeman RC, Narins GR, eds. Clinical disorders of fluid and electrolyte metabolisms (fifth ed). Mc Graw Hill, New York, 1994: 1099-119.

4. Rolla G, Bucca C, Bugiani M, Oliva A, Branciforte L. Hypomagnesemia in chronic obstructive pulmonary lung disease: effect of therapy. Magnesium \& Trace Elements 1990: 9 (3): 132-6.
5. Silverman AR, Osborn H, Runge J, Gallagher JE, Chiang W, Feldman J et al. IV Magnesium sulfate in the treatment of acute severe asthma. Chest 2002; 122 (2): 489-97.

6. Majkić-Singh TN. Metabolizam kalcijuma, neorganskog fosfata i magnezijuma. U: Majkić-Singh TN, Medicinska biohemija, Društvo medicinskih biohemičara Jugoslavije, Beograd 1994; 394-423.

7. Colardyn F, Verstraete A, Dheene P, Danneels C. Relationship between serum magnesium level on admission and mortality in patients in intensive care. In: Bennett D, ed. 9th European Congress on Intensive Care Medicine. Monduzzi editore, Bologna 1996; 229-32.

8. Whang R, Kennet W, Ryder MD. Frequency of hypomagnesemia and hypermagnesemia. JAMA 1990; 263 (22): 3063-4. 
9. Wong ET, Rude RK, Singer FR. A High prevalence of hypomagnesemia and hypermagnesemia in hospitalized patients. Am J Clin Pathol 1983; 79: 348-52.

10. Falkner D, Glauser J, Allen M. Serum magnesium levels in asthmatic patients during acute exacerbation of asthma. Am J Emerg Med 1992; 10 (1): 1-3.

11. Hashimoto Y, Nishimura Y, Hitoshi M. Assessment of magnesium status in patients with bronchial asthma. Journal of Asthma 2000; 37(6): 489-96.

12. Bodenhamer J, Bergstrom R, Brown D, Gabow P, Marax JA, Lowenstein SR. Frequently nebulized beta-agonists for astha: effect on serum electrolytes. Annals of Emergency Medicine 1992; 21(11) : 1337-42.

13. Harmanci E, Ekici M, Erginel S, Ozdemir N, Ozkan G. Comparison of effects of nebulized to intravenous magnesium sulfate on bronchial hyperreactivity and expiratory flow rate in asthmatic patients. Eur Respir J 1996; 9 (Suppl 23): 34s.

14. Amaral GC, Condino-Net A, Ribeiro GO, Toro A, Ribeiro $\mathrm{J}$. Oral magnesium reduces asthma morbidity in children and adolescents. Eur Respir J 2003; 22 (Suppl 45): 133s.
15. Silverman AR, Osborn H, Runge J, Gallagher JE, Chiang $\mathrm{W}$, Feldman J et al. IV Magnesium sulfate in the treatment of acute severe asthma. Chest 2002; 122 (2): 489-97.

16. National Heart Lung and Blood Institute-WHO. Global strategy for asthma management and prevention. NHLBI/WHO Worksop Report. Publication no 95-3659, Jan 1995.

17. Nagorni-Obradović Lj. Poremećaj elektrolita u akutnim plućnim bolestima. U: Bošnjak-Petrović V. Akutna stanja u pulmologiji. Savremena administracija, Beograd, 1995; $128-45$.

18. Mitić-Milikić M, Miladinović D, Vukčević M. Electrolyte disbalance in patients with chronic respiratory failure. Eur Respir J 1992; 5 (Suppl 15): 50s.

19. Hogg SJ, Mulrennan AS, Morice HA. Serum magnesium levels of patients with chronic obstructive pulmonary disease Eur Resp J 2003; 22 (Suppl 45): 107s.

20. Zervas E, Gaga M, Papatheodorou G, Kehagia V, Stoka $M$, Preza A et al. Magnesium levels in erythrocytes and plasma in patients with exacerbation COPD. Eur Respir J 2001; 18 ( Suppl 33): 429s.

Received: December 15, 2003

Accepted: February 10, 2004 